\begin{tabular}{l} 
RCCS \\
\hline Annual Review
\end{tabular}

\section{RCCS Annual Review}

A selection from the Portuguese journal Revista Crítica de Ciências Sociais

$2 \mid 2010$

Issue no. 2

\title{
The Solidarity Economy: An International Movement
}

Jean-Louis Laville

Translator: Karen Bennett

\section{OpenEdition}

\section{Journals}

Electronic version

URL: http://journals.openedition.org/rccsar/202

DOI: $10.4000 /$ rccsar.202

ISSN: 1647-3175

Publisher

Centro de Estudos Sociais da Universidade de Coimbra

\section{ELECTRONIC REFERENCE}

Jean-Louis Laville, « The Solidarity Economy: An International Movement ", RCCS Annual Review [Online], 2 | 2010, Online since 01 October 2010, connection on 10 December 2020. URL : http://journals.openedition.org/rccsar/202 ; DOI : https:// doi.org/10.4000/rccsar.202 


\title{
Jean-Louis Laville
}

Conservatoire National des Arts et Métiers (CNAM), Paris

\section{The Solidarity Economy: An International Movement ${ }^{*}$}

\begin{abstract}
This article describes the appearance of a solidarity economy movement in different national and continental contexts, stressing the diversity of practices within civil society at local and international level. Emerging in the last decades, these initiatives, which are both political and economic in nature, have extended and renewed the social economy, thereby offering a concrete alternative at a time of capitalist crisis. As such, the movement cannot be overlooked in the quest for a new economic model and public action.
\end{abstract}

Keywords: Solidarity economy; cooperativism; associations; self-management; participatory democracy; popular economy; the other economy.

In the last quarter of the $20^{\text {th }}$ century, associations and cooperatives began to make their presence felt again in the economy and in politics. In the words of L. Prouteau, "one of the most important aspects of the transformations that affected the associative world in the last quarter century is undoubtedly the increase in strength of its economic activities" (Prouteau, 2003; Demoustier et al., 2003). The second striking feature is the appearance of a worldwide civil society defined as the sphere of transnational activities and relations created by collective actors (social movements, civil society networks and organizations) that are independent of governments and private companies, functioning outside the state and the markets. This article describes the forms taken by this multidimensional process, emphasising the new issues raised by associations and cooperatives in some of their present reconfigurations. Today, as in the past, light needs to be shed upon this blind spot in order to look for new frontiers between the economy and politics.

\section{From voluntary to forced collectives}

During the "thirty glorious years" from 1945 to 1975, representative democracy and collective negotiation were the institutional means which enabled class conflict to be reabsorbed by compatibility between growth and solidarity at macrosocial level. In this context, the trade unions emerged as the voice of collective worker strength. The rights that were conquered at this time materialised in forms of indirect participation, which varied in breadth from country to country. Trade union power was extended to include consultation

\footnotetext{
* Article published in RCCS 84 (March 2009).
} 
on economic matters, with the appearance of works councils in Germany and consultative committees in the United Kingdom. However, in most countries, the powers attributed to workers' elected representatives resulted in limited conciliation in the social domain (working conditions, hygiene and safety, training, salaries, social works). In short, in the Fordist compromise, the trade union counter-power facilitated both the humanization and the acceptance of Taylorism. "The instrumentalization of the class conflict" (Dahrendorf, 1972) resulted in recognition of workers' forms of representation, instituted for the purpose of collective negotiation. This representative system reflected the implementation of an elitist conception of democracy in the workplace, as put forward by Schumpeter (1943). However, this approach was subject to criticism, particularly in the wake of the events of 1968.

\section{Self- management and alternativism}

Worker-led movements, which often involved immigrants and young workers who had little to do with the structures supposed to represent them, did not limit their activities to pay claims. Outside the industrial relations system, rebellions broke out against the so-called "scientific" organization of work and its dual specialization (vertical, separating the conception and execution of tasks, and horizontal, dividing work into repetitive gestures). "Work in crumbs" ${ }^{1}$ came in for criticism, and workers' demands for participation were taken up by trade unionists and politicians. This was the irruption of the self-management current in the intellectual field. At the start of the 1960s, critical thought was dominated by analyses centred on social control mechanisms. Then, the self-management current was put into action. Now, instead of refining the analysis of alienation, the objective was to combat it as swiftly as possible.

According to Mellucci, this expressed a refusal to allow modern capitalism to bring about a second expropriation on the cultural and symbolic level, following the earlier expropriation effected by the industrial revolution. The self-management current echoed the early association movement in that it distanced itself from the forms of representation granted to the workers' movement in industrial society. Moreover, it extended its criticism of production to the growth model. Anti-authoritarian and ecological movements were not centred on the division of wealth and did not approach social relations from a purely class

\footnotetext{
${ }^{1}$ After the original title of the book by Georges Friedmann (Le travail em miettes. Paris: Gallimard, 1956).
} 
perspective. They were oriented towards more qualitative demands for political rights to participation in power, bearing witness to Bell's "post-industrial society" and Inglehart's “post-materialism” (apud Neveu, 1996: 66-74).

The exceptional nature of the new social movements did not, however, denote unity. The contestation of the social division of labour and the demand for increased participation nourished two social transformation projects, in which "political militants" were differentiated from "alternatives". ${ }^{2}$ The militants remained loyal to the priority of political action, arguing for a return to the roots of socialism. Through the criticism of bureaucracy, they pointed out that the abolition of private property was not sufficient to realise the socialist project. However, they subordinated the adoption of self-management to the conquest of state power. The alternatives, for their part, sought to set up spaces of limited self-management immediately. This division between militants and alternatives may be illustrated by the anti-nuclear movement, part of which concentrated on the organization of large demonstrations, while the other also tried to prove the viability of renewable energies. This desire to change the "here and now" through experimentation explains why many of them turned to economic practices that would supposedly open up the way to an alternative economy. ${ }^{3}$

Reviving the connection with community messianism, these groups were convinced of the exemplary nature of their lifestyle in the modification of the normal relations between consumption and production. The legitimacy of their attitude was, for them, enough for its diffusion. Low income and work time were compensated for by the attention given to versatility, pay equality, discussions and reciprocal information. The experiments of these groups had a high failure rate. Most of the groups involved in the radical critique of notions of labour and employment ${ }^{4}$ disappeared. The maximalist nature of these aims proved to be to be inversely proportional to the durability of structures. Renouncing the prospect of an alternative economy, those groups that wanted (and were able) to survive lowered their aims, concentrating upon giving their members responsibility within collectively managed economic units that were inserted into the market. In some cases, companies formed in this

\footnotetext{
${ }^{2}$ Using terminology from Mothé, 2005: 53-60.

${ }^{3}$ Cf. Gendron, 2004: 400-402.

${ }^{4}$ Autogestions, 1981.
} 
way had access to market niches, thanks to the prior involvement of their members in political and social networks.

Far removed from its initial objective, this alternative dynamic gave rise to new forms of labour associated with the "post-industrial" service sector (Huber, 1981). Under its impulse, the cooperative work movement opened up to the provision of intellectual and cultural services in various countries. In 1985 , these cooperatives accounted for $45 \%$ of cooperatives and $32 \%$ of jobs in the service sector in the United Kingdom; $13.5 \%$ of cooperatives in Quebec; and $18.1 \%$ of cooperatives and $6.5 \%$ of jobs in France. In the fields of training, consultancy, technical studies, the media, arts and leisure, these small groups of skilled young people, who were often united by prior work experience in a company where they mastered customer relations, helped increase the number of new cooperatives and reduce their average size.

These alternative companies emerged as "imaginary projects of alternative societies" (Desroche, 1976), based on an "associationist" ideology that revived some of the $19^{\text {th }}$ century aspirations of Owen, Saint-Simon and Fourier. In their very functioning, they sought to anticipate an alternative economy "that would ideally bring together what contemporary society has set apart" (Vienney, 1980-1982). These companies quickly renounced their project to change society, either abandoning economic experiments or turning towards an innovatory business project, tending to prefer the status of cooperative as that best suited to the creation and management of companies controlled by those that worked in them. Thus, in the 1970s, the collective entrepreneurs that were behind work cooperatives prefigured company rehabilitation processes seen in the following decade.

The self-management current with its multiple ramifications could not resist progressive dilution. It was nourished by the social turbulence that prevailed after May 1968. However, opposition to the monopolization of information, professionalization and specialization of social functions and formalism of delegation practices, ceased to be grounded in an active social base. The difficulties and ambiguities of isolated experiments in an unfavourable atmosphere increased, and mobilization declined. However, this decline should not detract from the variety of experiments that resulted from it. Numerous companies were set up on cooperative lines, calling into question hierarchical modes of organization. Another feature of this dynamic was the connection established between the objectives of production and the means used to achieve them. Although it had not been taken into account in the 
previous cooperative movement, in this new wave of cooperatives, the mode of internal organisation was considered as a guarantee of the social and environmental utility of production. The matter of the objectives of the business was connected to the issue of its functioning.

For this reason, these may be termed "intervention collectives," ${ }^{5}$ as they advocated different labour relations and established a new horizon of change for themselves that went beyond their own limits as economic entities. They focused not only upon their own internal functioning but also aimed at broader action in society, postulating a connection between self-organization at work and the democratization of society. At first, they wanted to practise direct forms of democracy and were not satisfied with the representative models embraced in the cooperative statute. In addition, given the nature of the goods and services offered, they also aimed to preserve the environment and reduce inequalities. This was the case with studies offices dedicated to the new energies and to shops distributing biological products, and also with research associations, legal and management centres, and cooperatives dedicated to consultancy or training, whose aim was to place expert knowledge at the disposal of as many people as possible, so as to combat the "abuses of knowledge" (De Certeau, 1980). Though they did not trace the outline of an alternative economy, these intervention collectives created ruptures and raised issues that would be taken up again by the neoliberal wave of the 1980s. Despite everything, they would influence the initiatives that appeared later, hybrids inspired by the self-management movement and the struggle against impoverishment.

\section{Company acquisitions}

These voluntary collectives were connected to the crisis of values that affected the growth model of the "thirty glorious years." In the 1980s, the economic climate changed. Now, forced collectives, resulting from the economic crisis, began to play the most important role. In contrast with the period of full employment and "work in crumbs," some industrial work now began to demand cognitive specialization and intelligence. This explains the adoption of

\footnotetext{
${ }^{5}$ This expression was suggested to refer to the fact that, with regard to the kind of sociological intervention theorized by Touraine, it is not so much the confrontation between the mobilised group and the sociologists that makes the meaning of the action explicit as the debates that take place within the group itself, taking into account that the intervention group may itself exert the right of initiative and expression in favour of populations deprived of access to the public space (see Corpet, 1982; Corpet, Hersent \& Laville, 1986).
} 
participative management, putting self-management theories at the service of business. At the same time, free trade and the end of the restrictions on the capital market made it possible to transfer production to countries with low salaries and no social protection. The workers of multinationals were simultaneously ordered to get involved in production and exposed to the threat of job loss. This paradoxical injunction was associated with a defence of the replacement of public regulation (considered too restrictive) by an ethical form of regulation resulting from the voluntary action of companies. Pressure was exerted to lower wages and reduce social expenses.

With "corporate governance", the standards of profitability defined by shareholders, free to choose their investments in the international market, as between 12 and $15 \%$ of capital, transformed labour into an adjustment variable. This led to a multiplication of attempts to convert companies into cooperatives to save production, when this was considered viable by workers, even when it did not satisfy the demands of the international capital market.

After the revival inspired by the alternative ideology, the cooperative labour movement was profoundly affected by another wave of cooperatives, resulting from need rather than choice. These were worker takeovers. In Italy, despite a lack of rigorous statistics, there were around 1000 acquisitions between 1975 and 1985, mostly in the north of the country, in the textile/clothing, printing, small-scale mechanics, timber and transport sectors, which employed between 30 and 100 full-time workers on average. In Spain, worker takeovers not only took the form of cooperatives, but also limited companies of workers with employees holding shares in the majority capital; through the exact number is unknown, it probably corresponds to at least 1300 companies and 50,000 jobs. In France, between 1978 and 1983 (a period of unrivalled expansion of this dynamic), takeovers accounted for between 37 and $61 \%$, depending on the year, of all new cooperative jobs. These were the countries most marked by the phenomenon. In the United Kingdom, Germany and Denmark, takeovers were considerably less significant, with 90,13 and 14 in each of these countries respectively in 1986.

Considering the new profit standards of the international capital market, there were various ways in which a company could, nevertheless, remain profitable without attracting private investors. Employees thus found themselves confronted with the need to reorganise to make failing businesses profitable, sometimes using industrial reconversion projects. Takeovers were thus a logical reaction to more selective choices on the part of capital 
holders, but suffered from a poor "brand image," largely as a result of the politicization and media attention given to some cases. These ${ }^{6}$ tended to be companies with over 100 employees, where workers' power was strongly delegated in trade unions, which detracted from more successful acquisitions, mostly smaller companies in less capital-intensive sectors with highly skilled staff, where performance was connected to quality of work. These were the companies in which employees were most directly involved in the acquisition process, a decision that was not taken by the respective trade union leaders alone, even when they became managers of those companies. For example, in France, $63 \%$ of the cooperative model takeovers effected in 1981 were still operating five years later, a percentage that is better than the figure shown by all small and medium companies, of which over half disappeared during the first three years of trading. However, takeovers continued to be perceived as synonymous with failure, as public opinion was marked by resounding bankruptcies, such as that suffered by Manufrance.

In no country except Italy has the cooperative movement been able to construct an industrial sector from takeovers (and in that country the phenomenon is probably explained by the former strength of the movement). Attempts on the part of the state or trade unions to instrumentalize the work cooperative as a means of safeguarding large-scale employment changed suddenly, both in France with the union of the left, and in England under Tony Benn. Nevertheless, after these obstacles had been removed, less voluntaristic and more detailed accords were made between public entities, unions and cooperatives.

Some were introduced at national level, such as alterations in social security and unemployment insurance regulations, destined to encourage the unemployed to start businesses. Examples of these were the "enterprise allowance scheme" in the United Kingdom, and programmes to create advantages for company acquisitions in France and Spain. Local and regional authorities also increased their intervention in the economy to support businesses in their respective territories. Thus, in the United Kingdom, in 1986, around 80 cooperative support organizations received local government funding, particularly from Labour authorities. In France, decentralization facilitated the economic intervention of local authorities.

\footnotetext{
${ }^{6}$ Amongst the most well-known are: The Scottish Daily News, KME and Méridien in the United Kingdom (known as the "Benn" cooperatives, after the Labour minister who gave them his support), Clems in Italy and Tricofil in Quebec.
} 
Finally, certain trade unions went as far as redefining their relations with the cooperative movement. In Italy, the number of acquisitions consolidated was also due to the fact that the main unions, already associated with different cooperative federations in accordance with their respective political inclinations, committed themselves even further, signing an agreement in 1985 with the cooperative federations about the nature and volume of public support necessary for cooperatives and the joint efforts required to achieve that goal. In Quebec, the Confederation of National Trade Unions set up a consultancy group in 1986 to provide support in the domain of management to cooperative projects and to facilitate "the passage from formal democracy to participative management in daily operations." However, in most countries, union support occurred semi-clandestinely at local level. These examples contrast, then, with the failure of the previous widely publicized centralised support policies.

It is not only Europe that saw company takeovers. In many South American countries, affected by closures within the context of strategic reorientations by multinationals, there were many instances of "recovered businesses" (as they are called in Argentina, one of the countries where the phenomenon was most widespread). These companies aimed to both create employment and stimulate worker participation. While in Europe these acquisitions usually occurred after the period when self-management was the word of the day, in South America they were inseparable from a revival of the self-management initiative. Despite this, they experienced the same difficulties as European acquisitions. Although there were some economic successes, the initial enthusiasm was tempered by subcapitalization and by the technological obsolescence suffered by traditional industries such as textiles and footwear.

\section{The rediscovery of the popular economy}

The takeovers undertaken in the name of self-management, at a moment when this subject had already been abandoned in European debate, were part of a dynamic of large-scale updating of the popular economy. Despite the hopes invested in them, the spheres of the state and the export-oriented market did not permit wage integration to the extent seen in the North; there were entire sectors of the population deprived of access to formal employment circuits. In South America, between 1925 and 1950, the urban population had grown by $12 \%$ and non-agricultural employment increased by $87 \%$. On the other hand, from 1950 to 1960 , the creation of non-agricultural jobs was less than the growth of the urban population (59\% and 46\% respectively, dropping to $47 \%$ and $40 \%$ between 1960 and 1970). 
With the dictatorships and authoritarian regimes that interrupted the democratic experiments of the 1950 s and 1960 , not to mention the debt crisis and social deregulation that followed, a large sector of the active population was excluded from the formal economy (as much as half in a country such as Brazil). Once more, this population survived thanks to community-based forms of solidarity. The informal economy served as a refuge for $35 \%$ of the active population, according to estimates for Latin America. In this heterogeneous context, many commercial activities were left at the mercy of the outsourcing strategies of capitalist companies (some of which were illegal and used extreme violence). However, there was another part that formed a popular response to a difficult economic situation. As had happened almost two centuries earlier, the growth in more associative forms corresponded to an affirmation of solidarity in the perpetuation of habitual cooperation within primary groups. Labour was organized on the basis of collective mobilization, and the democratic management of projects was inseparably connected to survival.

Based on mutual help and shared ownership of the means of production, these popular associations included manufacturing workshops; ${ }^{7}$ organizations of the unemployed who sought work collectively; community food groups, such as collective kitchens and vegetable gardens; organizations dedicated to problems of housing, electricity and drinking water; precooperative self-building organizations, and associations for the provision of healthcare and cultural services to the collectivity. Santiago, Chile (where $25 \%$ of the work force operated within the popular economy) saw, over the course of ten years, a decline in food groups (from $54 \%$ to $9 \%$ of popular economy organizations), a growth in production workshops (from $53 \%$ to $68 \%$ ) and the development of activities to satisfy other needs beyond those necessary for mere survival (housing, health, education, etc.), as well as horizontal and vertical integration to reduce the isolation of the associations. Studies carried out in the whole of Chile show that the popular economy involved almost half of the active population and that $70 \%$ of workers did not wish to change, revealing an attachment to a particular way of life. These initiatives can be seen not only in Chile, but also in Argentina, Brazil, Colombia, Ecuador, Mexico, Peru and Uruguay. They are supported by black and indigenous movements (Alvarez et al., 1998: 333), as occurs in the countries of the Andes, where the principles of Indian organization are reactivated to generate original development models, such as the UN prize-winning Nasa project in Colombia. In this country, as in others, one of the most

\footnotetext{
7 "Talleres laborales" in Spanish (Verano, 2001).
} 
illustrative examples is that of the waste recycling companies. In Colombia, there are around 300,000 people ( $1 \%$ of the population) living off waste collection, of whom 50,000 are in Bogota. These people are victims of the formal and informal intermediaries to whom they resell, as well as suffering from a form of social contempt that assimilates them to the rubbish that they collect in the street. The creation of cooperatives, from 1987 onwards, resulted from a reaction against this ostracism. They aimed to fight dispersal and direct competition with intermediaries through an economic organization that could put them in a stronger position. In addition, these cooperatives also aimed to combat exclusion through a social, political and cultural organization that gave access to rights. This dynamic led to the grouping, in 1990, of the Bogota Recycling Association, on regional level, with the North Coast Association, and in 1991, on national level, with the National Recyclers Association, which brought together 88 of the 94 cooperatives, representing $10 \%$ of the population living off waste collection.

Another significant example is the Landless Rural Workers' Movement (MST) in Brazil, which came into being in 1984 . In 2000, 250,000 families reappropriated unoccupied lands that were unproductive. There were then around 50 farming cooperatives involving 2300 families and around 30 service cooperatives benefitting 12,000 families. Alongside the "Settlers' Cooperative System", there are hundreds of producers' associations operating as bodies through which credits can be received. There are 1800 primary schools with 3800 teachers and 150,000 pupils, 1200 nursery school teachers and 250 crèches.

These two examples have been assessed differently. As regards the recycling cooperatives in Colombia, the employee status acquired by workers, which grants them a uniform, social security, insurance and integration into a collective, has the effect of improving lives and work, helping these people escape what would otherwise be a form of social apartheid. However, the development of the cooperatives has been beset by problems of all kinds. These include the traditional individualism of the culture; the delimitation of responsibilities with non-governmental organisations, whose support is indispensable, but whose intervention may be perceived by members as interference; the confrontation with a process of privatization and rationalization of waste collection that offers opportunities while at the same time running the risk of benefitting larger companies; the resulting need for alliances with the private sector and the associated risks of re- 
absorption. As a manager of Rescatar (one of the main cooperatives) observed in a national meeting:

This is a globalized economy, it is universal. The same privatizations that are taking place in Colombia are taking place in Venezuela, Ecuador, Peru [...]. We are entering the twenty-first century, but we are stuck with the tools of 1900. We are one hundred years behind! We are competing in unequal conditions, with pushcarts and carriages, while the large firms own American or European trucks that cost two hundred million pesos. We cannot go on competing like this. [...] we have got to learn how to develop new projects. (qtd. by Rodriguez, 2002)

The MST, for its part, attracts controversy. This is due to its syncretism, in which the enthusiasm for agrarian reform and a "classless society," influenced by liberation theology and the Castro revolution, goes hand in hand with adhesion to traditional values of land, family and religion. The MST provokes both fascination and distrust as regards ideological "enchantment" and the "canonization" of collective action. The remarkable mobilization that it has brought about, amplified through its key role in the international movement "Via Campesina," has been questioned from the point of view of centralized control of its internal debates. Zander Navarro refers to a "mobilization without emancipation" of power by the control of financial resources and scorn for democracy - to which Martins de Carvalho retorts that the MST is a movement in construction, and that it not so much a mass social organization as a network of marginalized peasants from Latin America. For this author, present practices are explained by the discovery of new cultural codes, through flows of information and symbols, which, despite errors, forge an autonomous social identity. ${ }^{8}$ Emancipation is real, he argues, for many actors that were formerly illiterate but are now involved in a process of popular education.

The new wave of the popular economy has consequently been the target of controversial analyses. One point of reference is Razeto's contribution (1993), which stresses consolidation and democratization of economic practices, anchored in a community fabric, but effecting the reorganisation of that same fabric. Quijano (1998) is less optimistic, considering that individualism is imposing itself in grassroots organizations and that action is a result of need rather than solidarity. For this author, there really is a compromise, within those organizations, between the logic of capital and that of reciprocity, which constitutes an undeniable, though insufficient, specificity. These organizations are too dependent for us

\footnotetext{
${ }^{8}$ See the debate between the two: Z. Navarro, 2002: 189-232 and H. Martins de Carvalho, 2002: 233-260.
} 
to be able to speak, as Coraggio does (1999), of a labour economy that is opposed to the economy of capital.

In any case, the diversity of interpretations proves that the popular economy can no longer be understood as an archaic or temporary phenomenon, destined to disappear, according to the "iron law" of capitalist development. The recognition of the existence of popular economic knowledge becomes unequivocal from the moment that research is launched to understand the internal rationality of the initiatives. Even though these initiatives have not completely managed to escape marginal status, at least they are no longer limited to the mere management of extreme poverty. However, it is also true that many questions remain unanswered about the capabilities of this economy to get beyond the stage of simply reproducing living conditions to achieve the level of broader reproduction, or to move from the survival and subsistence level to certain forms of accumulation. There is a tension in the popular economy between technical efficiency and the dynamics of solidarity, between educating participants (many of whom are illiterate) and respect for the initial values that explain their commitment.

In any case, the perspective that once confounded this with the informal economy has now changed. Today, the grounds of the popular economy are considered to be deserving of attention. This recent interest results from legitimisation and puts pressure on public authorities to confer full rights to this economy. In this context, there are already nongovernmental organizations sensitized to the subject and active in the area, and university networks have also been set up in some countries, such as Peru, Mexico, Argentina, Colombia and Uruguay. However, it is Brazil that has advanced most in this domain. Since 1980, "Caritas" has financed thousands of "alternative community projects"; in 1999, the Central Workers' Union (Central Única dos Trabalhadores or CUT) began to commit itself strongly through its Solidarity Development Agency (ADS). Dedicated to training and the dissemination of information amongst both union militants and cooperatives, this agency was set up in partnership with "Unitrabalho," which groups over 80 universities; it led to the creation of the University Network of Technological Incubators of Popular Cooperatives (ITCP), which helps launch cooperatives and associated production groups.

The popular economy has thus regained a visibility in recent years that had been lost. While connections remain tenuous between the "self-managed" businesses that resulted from industrial bankruptcies and the new cooperatives offering services (such as cleaning, 
recycling, artistic production, training, etc.), various church, union and university groups today support the popular economy, together with various movements aimed at emancipation and the defence of rights, such as ecological organizations.

In these expressions of the popular economy, what is at stake is in fact an accentuation of its public dimension. According to Hirschman (1971), in the popular economy initiatives of Latin America, the fight for better living conditions is intrinsically linked to the fight for the rights of citizenship. This struggle oscillates between protests and self-resolution of problems, without separating material questions from questions relating to living conditions and co-existence. In the words of Scholnik (1984: 28), "it is a different way of doing politics." The same point is made by women's' groups opposed to the dichotomy between public and private, production and reproduction, which allocates unpaid jobs to women that use up two thirds of their respective work time, while two thirds of men's work time is remunerated. Historically, women's confinement to an overlooked domestic economy explains their physical and symbolic underrepresentation in the public sphere. Women are in the majority in popular initiatives because they consider that these collective initiatives might help identify and contextualise their needs, so that they can express them and bring them into the public sphere. Given the failure of standardised universal measures, these initiatives are a means of consolidating rights and translating them into capacities for action, thanks to the collective, which is a resource for developing self-confidence, relieving the weight of responsibilities assumed in the family sphere and reconciling them with a commitment to social justice. These collective actions aim first and foremost to be pragmatic responses to the problems of daily life. However, they also formulate societal and environmental claims, establishing a link with ecological feminism in opposition to a materialist and economicist conception of wealth that assimilates domestic knowledge to "innate" qualities, to "altruism" and female "obligations."

\section{Some local and international initiatives}

The experiences of the South in the sphere of the popular economy have provided the impulse for a shift in attitudes to proximity activities that involve caring for others, including a more equal distribution of these tasks and heightened awareness as to the wealth that they generate. In this plane, they are very close to activities undertaken in the North under the name of proximity services. 


\section{Proximity services}

In the Scandinavian countries, there are new organizations that operate quite differently from traditional associations. Diverging from the hegemonic cultural and political approach of the 1970s, these organizations proposed new organizational forms and solutions to local social problems in the 1980s (Klausen \& Selle, 1996: 99-122). These included publicly supported organizations known as "project promoters" in Denmark, whose mission was to encourage citizens to shoulder responsibilities in social policies on a voluntary basis. In Sweden, women's groups set up shelters and counselling services for victims of domestic violence, which led to over half the town councils implementing public initiatives providing support for women. Also in the 1980s, parents' groups began to organise childcare facilities, because, in their view, the public services were not responding to all their needs, neither quantitatively nor qualitatively, given the standardized functioning of crèches. The social democrat government granted these childcare cooperatives the right to be $85 \%$ financed by public funds. Later, in 1991, all restrictions were lifted regarding the legal status of the organizations working in this field. $15 \%$ of children under school age are now in nonmunicipal crèches, of which the majority are parent-run cooperatives. Others are work cooperatives or associations (Pestoff, 1998, 2004). Indeed, in this context, cooperatives and associations participated not only in the reorganization of existing services but also in the creation of new ones. The "cooperatization" (Lorendahl, 1997) of social services is primarily a way of increasing the role of users, as in the case of the parent-run crèches, and was accepted under the pressure of the financial constraints affecting the public sector.

In the United Kingdom, in the 1990s, associations representing cultural minorities and the disabled developed radical approaches that stimulated user participation in the organization of the services aimed at them, thereby countering what their spokespersons called the paternalism of the authorities and the blindness of the market. In local development, there appeared grassroots "community" approaches, such as the "community transport association" (nationally recognised as the representative organ of groups that came together to compensate for the lack of special needs transport), "community enterprises" (numerous in Scotland), "community foundations" and "community development trusts". All these initiatives took place in urban and rural areas where the market economy was in decline. They aimed to induce a new dynamic in these areas, developed within the population itself. In the area of environmental protection, over 3000 projects were developed by 
"groundwork trusts" with local people participating in their design and implementation in partnership with ecological associations, local groups and companies. In childcare, "playgroups" were organised for small children on a part-time basis. These parent-run organisations developed in reaction to the lack of supply, and by 1998 there were 18,000, accounting for $19 \%$ of vacancies available for children under five (Taylor, 2004).

In Germany and Austria, mutual help initiatives reflected people's desire to take responsibility. These could be divided into three subsectors: semi-informal groups, self-help groups (i.e., groups of people affected by the same problem) and groups that defended the causes of certain sectors of the population though without belonging to those groups themselves. These were mainly voluntary, with paid professional work playing only a complementary role. There were 70,000 initiatives of this kind in Germany, involving around 2.65 million people (Evers et al., 1999). From the 1980s onwards, they multiplied, particularly in the areas of healthcare and social work, with 5,000 to 10,000 groups operating in healthcare alone. These organizations took root in a spirit of criticism of the bureaucracy of public services and large-scale welfare organizations. This led to the appearance of new local organizations. In Vienna, for example, childcare for 65,000 children was secured half by public service and half by associations, either traditional or resulting from these grassroots initiatives (Leichsenring, 1997).

In France and Belgium, new forms of association also appeared, in recognition of the fact that lack of profit did not in itself guarantee user respect. In this context, associations, for a long time the main service providers, enjoyed a near local monopoly. They gradually opened up to competition and many tried to improve their performance by implementing business management models, such as the use of marketing tools. However, while this standardization yielded poor results, ${ }^{9}$ other associations made an effort to find a specific niche, developing initiatives that emerged around an approach that did not confuse the user with the consumer. These innovations, whether renewing old associations or creating new ones, took the practice of original associative functioning as their central challenge. According to their promoters, the long-term legitimacy of the associations' services depended upon these organizations' ability to encourage user participation, in Hirchsman's sense of using "voice" (Pestoff, 1998), as well as mobilizing volunteers and finding

\footnotetext{
${ }^{9}$ For a demonstration of the perverse effects of the administrative professionalization of associations, see the introduction in Laville \& Sainsaulieu (1997).
} 
appropriate financial equilibrium in a less protected sector. In France, one example of these innovations was childcare establishments involving parental participation. These started off as "crèches sauvages" ("wild crèches"), which broke with the traditional medicalization, separation and specialization of the collective forms of childcare, achieving recognition in 1981. Their development was marked by two trends. The first was the enlargement of the categories of initiators. Many establishments were started by professionals that wanted to be self-employed, or upon the initiative of local groups or institutions. The second was the expansion of the target public. Having begun as a specifically urban (even Parisian) phenomenon, the parental crèche movement spread due to its pliancy. It diversified to include part-time childcare without the need for exorbitant investment, costing a third less than other collective structures on average.

The breadth of the phenomenon of proximity services might appear modest. However, they began to be recognised at national level in experimental social and economic policies, such as the "youth jobs" programme in France. At European level, the "white book" (an EC reflection paper for the 21st century) was the first to mention them, announcing "three million new jobs" that could be shared "equally amongst the proximity services, the improvement of living conditions and environment protection" (European Commission, 1993: 13). The surveys carried out by the Commission defined the areas of activity of what was known as "proximity services" in French-speaking countries and "local development and employment initiatives", using the more consensual European Union terminology (Jouen, 1995). Four large fields are listed (European Commission, 1995, 1996): everyday services (domestic help, childcare, information and communication technologies); services aimed at improving living conditions (housing, safety, local collective transport, the enhancement of urban public spaces, proximity commerce, the valorisation of the cultural heritage, cultural development, sport); and environmental services (waste management, water management, protection and maintenance of natural zones, regulation, pollution control and the corresponding facilities). ${ }^{10}$

Originating with the restructuring of social services, proximity services could not get away from the fact that one of the main causes of the growing inequalities was the rise in unemployment and exclusion. Thus, insertion services were developed by economic activity, with the main objective of finding employment for people in difficulties; the choice of

\footnotetext{
${ }^{10}$ For a summary of local initiatives in Europe, see Gardin \& Laville (2000) and Gardin (2006).
} 
activity was made in accordance with its capacity to offer access to salaried work. The greatest problem with the services set up to further insertion was to promote this aim without participating in the extension of derogatory statutes to common law, which accentuated the decline of the salaried workforce by instituting a second job market. These initiatives aiming at economic insertion combined social support with the quest for economic efficiency, and as such were pioneers in active policies related to job markets. They oscillated between a simple "SAS" (simplified joint-stock company) function, in the sense of the market economy, and a desire to associate people involved in the management of a production entity. The aim pursued was either a simple provision of insertion, limited to providing training to future employees of private companies and teaching them the rules of discipline, or was, more broadly, to include them as full-rights subjects and economic actors. $^{11}$

These experiments may be grouped together on the grounds that they propose a new concept of services for people. Services organized in this way may be termed "proximity services," if we understand proximity not only in spatial or temporal terms, but concerning the subjectivity of actors. Proximity may obviously take the form of neighbourhood, because, in most cases, the services are provided over a restricted area and are able to swiftly respond to user demand. However, this proximity should not be confused with the concept of neighbourhood. Proximity is defined by the fact of being felt, experienced and internalized by the actors. Instead of each person trying to cope with their daily problems individually in the private sphere, proximity services propose to deal with them by opening up the private sphere to the public sphere. At first, there may be only a few people that begin to broach matters amongst themselves that they have not spoken of previously. But when the discussion starts to include these multiform realities, supply and demand can be adjusted.

For all these reasons, despite differences of context, some aspects of the popular economy, described above for the societies of the South, are also present in proximity services. If we do not limit needs to material needs, what is at stake is fundamental aspects in the process of formation and reproduction of a human society. This is clearly not about

\footnotetext{
${ }^{11}$ For a summary of the paradoxes of insertion, based on the French case, see Eme (2005). An overview of initiatives at international level is provided by Defourny, Favreau \& Laville (1997) and Nyssens (2006); the diversity of insertion initiatives in Europe is detailed, mentioning different scenarios.
} 
subsistence but rather about equality of access and respect for human rights in services. However, it is in fact a feeling of belonging that leads to involvement, even if there is no inherited identity, but only an identity constructed through collective action. The equality of members constitutes the rule, even when experiments are less connected to a type of actor than to a negotiation between various types of actors (users, salaried workers, volunteers, etc).

The powerful convergence between the contemporary popular economy of the South and proximity services of the North has to do with the valorisation of knowledge connected to the provision of services. In proximity services, there is a deconstruction of the gap between private and public, which does not correspond to women's experiences and neglects the skills of education and mediation involved in affective work that contributes to the wellbeing of children, dependents or the sick (Folbre, 1997). ${ }^{12}$ As in the South, it is important, primarily, to remember that this care was traditionally provided by the family, and within the family, by women. Against such gendered division of labour, it is important to argue that these activities are crucial and ground the meaning of life in society. Rather than creating a dissociation and hierarchization between economic, political and domestic space, with men at the centre of the first two and women in the third, like an enclave, adoption of the perspective of a decent life and human welfare leads us to affirm that "it is impossible to choose not to care or not to work" (Lewis, 2003). Care cannot, therefore, be totally outsourced to the state or the market, as this would not take account of the intergenerational transmission of skills, instrumentalizing them in the name of job creation, without assessing the respective anthropological substratum. Care services are therefore a public asset, and ensuring their provision presupposes, on the one hand, a sharing of responsibilities among not only family and public authorities, but also the market and civil society, and on the other, a sharing of intra-family responsibilities between men and women, presupposing equal opportunities in the job market. This sharing should be debated in the framework of a reflective society where political problems are also matters of everyday life and gender relations. ${ }^{13}$

\footnotetext{
${ }^{12}$ It is the issue of "care" that is raised here.

${ }^{13}$ For an in-depth exploration, see Guérin (2003; 2007: 282-304).
} 


\section{Fair trade}

Proximity services are consequently part of this long history of local initiatives that goes back to the popular economy. The greatest novelty, on the other hand, was the appearance of initiatives developed in the North and South. If the responses were comparable, this was because the neoliberal policies implemented in the South, whose content was summed up in the Washington consensus (great openness to international competition, increased recourse to market mechanisms to the detriment of public regulation and privatization of public services), also impregnated public choices in the North.

From the beginning of the 1980s, international financial institutions began to condemn industrial and social policies as ineffective, giving priority to economic liberalization, reform of public finances and privatization of healthcare services. The search by governments for ways of restoring growth received a universal response, according to the Washington consensus: increased recourse to market mechanisms free of state regulation; minimum public intervention; marked openness to international competition. The World Bank and the International Monetary Fund gained importance by making their support dependent on the so-called structural adjustment policies. The corollary of this was that the increase in social differences, unemployment and poverty within each country became as sensitive as the growth in social inequality at world level.

The countries of the South, dominated by oligarchies connected to the elites of the North, have long opted for a mode of development that is dependent upon the export of raw materials and farming products. Since its creation in 1994, the World Trade Organization has accentuated the deterioration of the terms of trade, because the prices of these products tend to increase more slowly than the prices of industrial products in the North. This commercial openness, unaccompanied by any binding social and environmental regulations in international legislation and combined with austerity measures at national level, affected many hundreds of thousands of peasants throughout the world, primarily because the reduction of public intervention proved selective. The maintenance of strong subsidies enabled rich countries to export at such low prices that they brought about the disappearance of local producers. At the same time, a series of technical requirements were set up, such as customs barriers against imports. In reality, countries have unequal negotiating powers, and multinationals interfere in international agreements, controlling half 
of world production and two thirds of world trade. ${ }^{14}$ According to the United Nations

Development Programme (UNDP), international trade is $82 \%$ controlled by countries home to only a fifth of the world population, while the countries of the poorest fifth control less than 1\%. Developing countries participate in around $30 \%$ of international trade of goods and have even less of a presence in services and financial flows.

It was against these injustices, guaranteed (if not actually increased) by international institutions, that fair trade was established. This aims to oblige commercial relations to have respect for producers and for the environment. According to FINE, an association of four international fair trade networks, "Fair trade organizations, backed by consumers, are engaged actively in supporting producers, awareness raising and in campaigning for changes in the rules and practice of conventional international trade." ${ }^{15}$ Resulting from the encounter between representatives of the South, who demanded that development aid be converted into fair trading practices, and ecological and human rights associations in the North, fair trade established two aims from the outset:

- To improve the life of small producers in the South, marginalized for lack of financial resources and experience, by creating commercialization channels for their agricultural produce and handicrafts to consumers in the North that wish to contribute to a greater solidarity between North and South;

- To set up a network of consumers by raising public awareness about the injustices of the rules of international trade and by carrying out actions targeting political and economic decision-makers. (Ritimo-Solagral, 1998: 15)

The first form of intervention was the direct sale of handicrafts and agricultural produce from the South through the "World Shops", which appeared in the Netherlands in 1969, on the initiative of associations and cooperatives of international solidarity. There are now more than 3500 shops in 18 European countries, managed by 60,000 volunteers and 4000 paid workers. Their growth rate is $20 \%$ per year, though national disparities remain (for instance, the turnover in Holland is $\mathbf{5 0 0}$ times higher than in France). The products are imported by "Alternative Trading Organizations" (ATO). The first of these purchasing centres was set up

\footnotetext{
${ }^{14}$ As Agir ici reveals, $70 \%$ of Senegal's chicken farming (for meat consumption) disappeared due to the mass importation of chicken pieces from Europe (Campagne "Agir ici", No. 68, October 2004).

${ }_{15}$ Quoted in "EFTA, Joining Fair Trade Forces," EFTA, February 2006. http://www.european-fair-tradeassociation.org/efta/Doc/What.pdf.
} 
by Oxfam in 1964; today, there are more than 100, and the 12 most important are members of the European Fair Trade Association (EFTA) set up in 1990. EFTA imports 60\% of equitable products into Europe from 800 groups of producers from the South, that is, from 46 different countries, representing 800,000 families (around 5 million people). Its role is to guarantee respect for certain criteria in purchases and in relations with producers: the establishment of long-lasting relationships and pre-financing of production; limitation of speculative intermediaries; control of social and ecological conditions of production; support for local development projects; information about the functioning of the international market; the payment of a "fair price", which takes costs into account and guarantees a reasonable standard of living. Since 1994, fifteen federations of world shops from 13 countries have come together in the Network of European World Shops (NEWS!) to harmonize national progress, help in the coordination of that progress and organize European awareness campaigns, targeting not only consumers but also public authorities.

In 1988, the Max Havelaar initiative appeared in the Netherlands to expand trade. Its aim, which was embraced in many countries, including France, was to ensure the equitability of products by attributing a label. In fact, this was a certification, as under French legislation the label itself presupposes the existence of specifications for each product, issued by an independent controller, as well as an approval document from public authorities. Soon, more than 16 other national associations had appeared in Europe, North America and Japan. In 1997, these associations provided the impulse for the "Fair Trade Labelling Organizations International" (FLO International) to homogenise standards per product type, support and reinforce producer organisations and facilitate access to commercialization for their products. FLO International covers nine sectors (coffee, tea, cocoa, sugar, rice, honey, fresh fruit, fruit juice and footballs) and involves 357 producer organizations in 46 countries of the South (around 800,000 families). The products are sold at 70,000 points-of-sale, including 50 of the main distribution chains and 33,000 medium-sized supermarkets.

Thus, initiatives vary, depending upon whether direct sales or certification is preferred. This is reflected in different strategies with regard to consumers. The importer-distributors, like the world shops, react against a kind of trade in which producer and consumer do not know each other. What is important is to dominate the sector in order to better remunerate the producer and recover the human and cultural dimension of trade, enabling the buyer to understand the conditions under which the goods are produced. Anonymity is replaced by 
personalization, which has meant that the reality of lifestyles in the countries of the South has become perceptible for consumers of the North. For certification organizations, the priority is not restricted to militant purchases, but rather to make fair trade known to the public at large, placing products at their disposal at as many points-of-sale as possible.

There are increasingly lively tensions between these orientations. Nevertheless, international groupings such as the "International Federation for Alternative Trade," founded in 1989, and FINE, which covers the representative organisations (FLO, IFAT, NEWS! and EFTA), defend the concerns common to all components of fair trade, contesting the unequal representation of countries in the present functioning of the WTO, the subordination of social and environmental rights to economic interests, and the systematic opening-up of the market to the detriment of food sovereignty. Alliances are made with trade unions and consumers' associations ${ }^{16}$ with the aim of questioning companies about their social practices and the social practices of their subcontractors regarding "decent" working conditions, according to the standards of the International Labour Organization. Campaigns are also organized to influence national and international legislation.

So as not to reproduce the scheme of conventional trade, according to which the countries of the South are no more than suppliers for the North, it is important to include workers from the South in the definition of criteria, establishment of prices and assessment of actions. It is also important to stimulate more limited sectors, facilitating the implementation of forms of public regulation subject to simultaneous control by public authorities and local organizations of civil society. From this point of view, fair trade, conceived from a critique of North-South relations, extends to South-South and North-North dynamics. The militants' main concern is to reduce the environmental costs connected with long-distance transport, and to progress towards an economy that is more self-centred in terms of regions or sub regions. The model of the "Associations pour le maintien d'une agriculture paysanne" (associations for the preservation of peasant farming) (AMAP), in France, illustrates the appearance of North-North networks. In this case, a group of consumers makes a contract with a peasant farmer, buying his produce in advance at a mutually agreed price for an established period that is long enough to imply a sharing of the risks. Consumers meet regularly with the producer to stock up on fresh natural food, and a committee of volunteers ensures the functioning of the association. This new perspective,

\footnotetext{
${ }^{16}$ As happens with the collective "De l'éthique sur l'étiquette" in France.
} 
which corresponds to local fair trade, is also stimulated in Latin America, as can be seen in the "Latin-American Meeting on Fair Trade and Ethical Consumption in the Perspective of Global Solidarity," held in Lima in 2001. One of the successful outcomes of this meeting was the Latin American Network for Community Trade (RELACC), which covers 12 countries. Its aim is to promote the increase in national trade by reducing intermediaries, so that producers, who are mostly indigenous and rural, can receive a better price for their produce. As for the consumers, they have access to essential products at a reasonable price. In Peru, over 3000 popular restaurants are supplied in this way. Another example of the South-South dynamic is the "Mexico Fair Trade" label for commercialization on the national market.

As these different examples show, the growth in fair trade has been so spectacular since the 1990s that it runs the risk of imploding. In fact, for some initiatives, the increased volume of business has been dramatic, resulting from a greater awareness of consumer power. Others remind us in vigorous terms that the international campaigns in defence of the rights of workers in the South count more than the volume of transactions. Awareness raising is as important as fair trade, which should achieve a sufficient threshold to interpellate world trade, without becoming banal. ${ }^{17}$ Despite these divergences, the impact of fair trade is undeniable and not limited to the sectors in which it is implanted. The questions raised by this trade are multiplied by those deriving from the point of view of responsible solidarity consumption ${ }^{18}$ and may also be transferred to other domains, and related to those that are formulated by equitable and solidarity tourism networks (Collombon, Barlet \& Ribier, 2004). Liaising with other movements which act in the same direction, like microfinance, fair trade helps challenge the dogma of free trade.

\section{Microfinance and social currencies}

This is not a coincidence, but a reaction to the same process of deregulation. At the same time as fair trade began to protest about the growing marginalization of small farmers, means of popular funding began to be sought that could overcome the problem of banking exclusion, which afflicts many entrepreneurs in the "conventional" circuit. Particularly

\footnotetext{
${ }^{17}$ This has led to debates about limited commercialization in world shops, given the opening-up to large-scale distribution, and about the balance between volunteer work and professionalization. For the French case, cf. the publications of the Fédération Artisans du Monde, which also publicizes those edited by the collective "De l'éthique sur l'étiquette."

${ }^{18}$ On responsible solidarity consumption, see also Mance, 2006.
} 
through the intervention of non-governmental organizations, support mechanisms have been created to help launch businesses.

One of the main ones is microcredit. Conceived as part of the fight against poverty, its rapid success means that it is a simple tool offered as a solution to disadvantaged groups. World microcredit summits have enthusiastically set a target of 100 million customers; however, there are ambiguities, such as the reduction of the initiative to a single model, and the use of the theme of the initiative to foster a critique of the wage system.

Firstly, the range of possible initiatives is reduced to the single model of the individual entrepreneur. The capacity for initiative that arises in society is limited to a "barefoot capitalism" (De Soto, 1987) which does not distinguish the diversity of real processes. In fact, as revealed by research undertaken in the countries of the South, the popular economy cannot be interpreted in these terms. Some women's initiatives (Guérin, 2003) are symptomatic of this perspective, as they cannot be analysed according to the individual company model. They are generally part of a collective initiative for the improvement of daily life. The women that participate in them are involved in sectors connected to everyday life, converting their traditional knowledge into professional skills. In the North, similar initiatives also exist, such as neighbourhood restaurants, catering services, mediation services, etc. The originality of these initiatives has to do with their collective dimension, and it is the economy and citizenship that are at stake. Their promoters are motivated by a desire to be actors in their own lives and agents of social change. At present, the increasing number of business ventures led by women's groups face problems with recognition and credibility, which limits their implementation and durability. To recognise the capacity for innovation of women's initiatives, like others, presupposes the integration of their forms of collective organization (Berger, Fraisse \& Hersent, 2000).

Another characteristic feature is that the multiplication of independent micro-businesses is presented as an alternative to the protectionist rules of the wage system. According to this analysis, state intervention, which caused a damaging rigidity, should be replaced by a private sector that is motivated by concerns with social welfare. Consequently, the discourse of microbusiness is ultimately sustained by arguments that defend state non-intervention. As in the $19^{\text {th }}$ century, the fiction concerning the contractual equality of individuals is used to mask unequal power relations. However, this ideological reading is also undermined by the facts. In reality, experiences involving support to successful initiatives draw on relationships 
of trust and territorialised action. Associative mediation seems, therefore, to be indispensable. Moreover, no experiment can today be considered entirely public or entirely private. While public funding is essential for associations, one way of limiting dependence upon it is to develop banking partnerships through guarantee funds. Solidarity credit mechanisms that aim to get beyond the experimental stage have chosen this path.

Some of the organizations that have appeared in the South have consequently distanced themselves from the attitude that regards microcredit as a panacea. Experiments that are more critical of the banking system and more oriented towards combating the structural causes of inequality are gradually distancing themselves from microcredit to defend a more political and less functional position, affirming their solidarity commitment and conceiving their practices as a new form of collective action and public intervention (Servet, 2006: 439465). Solidarity microfinance systems also offer loans without previous savings, but they are distinguished by the type of entities supported, the operations carried out and resources mobilized. They are open to both collective companies and activities that have an ecological or social purpose, and aid in the form of credit is supplemented by other services (such as guarantees, risk capital, insurance etc) and investment at the project monitoring phase; they combine savings drain, in which subscribers may voluntarily renounce part of their remuneration, and participation in public funds. In short, these initiatives submit financial interventions to a socialization process that distinguishes them from microcredit, which is indifferent to the utility of production and centred on the figure of the individual entrepreneur. On this basis, solidarity finance has conquered the countries of the North. Thus, in Europe, institutions in eleven European countries have joined the European Federation of Ethical and Alternative Banks (FEBEA) since it was set up in 2001. The aim is to encourage saving and solidarity investment, primarily through favourable taxation. One promoter is the "Banca Popolare Etica" ("Popular Ethical Bank") in Italy, a meeting point for investors that want to manage their money in a more responsible and conscious way, and are interested in socioeconomic initiatives that subscribe to principles of sustainable human and social development. At the moment of depositing their money, investors can choose the areas of activity in which the funds will be applied: healthcare, welfare and education; social exclusion; environmental and heritage protection; development and international aid; fair trade; quality of life, promotion of sport for all and cultural initiatives. 
Europe has a history of "social" banks characterised by a concern for disadvantaged populations and territories, and a desire to make funding available for all. These are: municipal credit banks; mutualist and cooperative banks; savings banks in the form of public establishments in Luxembourg; municipal foundations in Germany; trusts in Greece and Portugal; non-profit establishments and cooperatives in France (Glémain, 2006). Around 54\% of the social banks in Europe are savings banks, and 18\% of the European banking market consists of cooperative banks (Richez-Battesti et al., 2006). More precisely, the present movement renews the connection with the idea of popular credit present in France in the mid 19th century with Proudhon's exchange bank project, Raffeisen's mutual agricultural credit bank and Schulze-Delitzsch's popular bank in Germany, and later, the "credit unions" in the United Kingdom. This new connection is made through a return to original aims on the part of the old mutualist and cooperative banks, as well as through the appearance of new operators. In the first case, we can cite the "Cooperative Bank." Founded in 1872, this seemed to have gone into unstoppable decline in 1990, when, to the great surprise of the cooperative movement, it reinvented itself as an "ethical bank" and resisted an attempt at demutualization on this basis (Yeo, apud Taylor, 2004: 134). In the second case, we could mention, in France - where only $22 \%$ of new companies obtain bank funding (Alcoléa-Bureth, 2004: 245-292) - the case of institutions that intervene through participation in capital and loans at regional level, such as Femu Qui, in Corsica, or Herrikoa, in the Basque Country; and at national level, the Nouvelle économie Fraternelle (NEF) or the Clubs d'investisseurs pour une gestion alternative et locale de l'épargne (Clubs of investors for alternative local management of savings) (CIGALES). For the latter, the federation has enabled support from over 350 companies and the creation of 1800 jobs with 12 million Euros invested. As regards proximity and solidarity risk capital, this involves 7000 shareholders for around 6 million Euros and supports 650 companies. Since 1995, the association Finansol (Finance and Solidarity) has gathered and publicised experiments. Despite a certain heterogeneity, the organizations of Finansol mostly consider themselves as instruments that cannot limit themselves to individual aid to combat the polarization between rich and poor, and instead reinforce social networks, protecting the weakest and their collective actions.

This concept of money at the service of social ties is extended in the exchange of goods, services and knowledge, organised through social currencies (Blanc, 2006). This is no longer a question of democratization of access to the official currency, but the creation of a unit of 
calculation to be shared amongst the members of the same association. Unlike national currencies, social currencies, which are issued by a group of citizens that gives them a name, are currencies that escape state monopolies. They are designed to develop interpersonal relations, constituting spaces of trust where rules of trade are negotiated, which enables local capabilities to be valorised beyond those that are mobilized by mercantile production. The general idea consists of replacing contractual exchange based on individual independence with enrolment in a social network that aims to be convivial and in which multilateral exchanges can take place, creating clientele ties ${ }^{19}$ amongst all members that last after the transaction and encourage the renewal of alliances. Social currencies do not exist before the transaction; they are rights issues, and circulation, rather than hoarding, is encouraged (for example, when they take the form of currencies "that melt," i.e., when accumulation and retention are penalized with a reduction of value).

These currencies had precedents. One of the most famous appeared in the $1930 \mathrm{~s}$ in Austria, where a local currency was created to combat the economic depression. This currency was prohibited by the central bank. There were also local currencies in the 1950s in France and Brazil. But their contemporary expansion has been much more marked. In 1983, "Local Exchange Trading Systems" (LETS) appeared, involving, according to the scanty information available, over 1.5 million members spread over more than 2500 associations in around thirty countries, particularly in the West, Latin America and Japan.

In particular systems, such as the Italian time banks, French local exchange systems (SEL) and the German Tauschringe, the national currency equivalent of the unit chosen is rejected, as the objective is to stimulate a different value system. Reviving notions that were in force in the early 19th century, put into practice in Owen's equitable labour exchange, these systems transferred value and services completely to work without any kind of deduction. It is time spent that counts in a framework that reveals a common identity; for it to function dynamically, involvement in activities should be regularly repeated. To stimulate these egalitarian and participative relations, regular meetings are held and a spirit of playfulness is cultivated in the evocative names given to the monetary unit and by the frequency of the exchange. LETS in Anglo-Saxon countries such as Australia, Canada, New Zealand and the United Kingdom have a slightly different aim. Like solidarity finance, they primarily challenge

\footnotetext{
${ }^{19}$ On the difference between "market place" (place du marché) and a relation of "clientele ties", in the context of the word "market", see Servet, 2006: 314-316.
} 
the exclusion that results from monetary orthodoxy, and their action is focused upon the encouragement of means of payment that can go some distance towards restricting the money supply. In this context, it is logical for social currency to be partially converted into national currency and for opportunities to be created for inter-LETS transactions. This is less about seeking practices based on different grounds than about achieving insertion in increasing economic flows.

With their rapid expansion, local exchange systems were often interpreted as the vectors of a spontaneous economy based on mutual help. In 2002, Argentina had over 5 million members, but this growth only lasted a short time before collapsing. Except for this particular case, the typical cycle was less irregular. Rapid construction was usually followed by a certain slowing-down, as happened in France, where the number of SEL stopped growing in 1998, and then diminished slightly to around 315 for 30,000 members in 2000 . These facts meant that the dream of a new paradigm for society had to be replaced with a more modest intervention capacity, which helped legitimise initiatives in the economy, irrespective of capital ownership. From this perspective, local exchange systems are close to other experiments that have stayed clear from the official currency in the transactions that they stimulate. Two examples may be given in Francophone countries. The first is that of the monitored self-production networks that have begun to group into associations: neighbourhood workshops, collective kitchens, family nurseries, self-built and selfrehabilitated housing, leisure, repairs, etc. ${ }^{20}$ Support can take many forms and for this reason, alignments are not immediate but derive from self-production, in the sense of activities aimed at the production of goods and services for self- and neighbourhood consumption (Cérézuelle, 2004: 101-108). The second example concerns reciprocal knowledge exchanges, which were organised into a movement several years ago (HéberSuffrin, 1998: 417). Each of these networks establishes non-hierarchical relations between suppliers and users of knowledge of all types: "from practical knowledge (such as how to fill in forms) to classical knowledge (literature, musical instruments) and even technical knowhow (using computer software, cooking, gardening, etc.)" (Héber-Suffrin, 1992). In these two examples, as in the case of local exchange systems, the associative framework is conceived as

\footnotetext{
${ }^{20}$ See the website of PADES (Self-production and Social Development Programme): $<$ www.pades.autoproduction.org $>$.
} 
"an attempt at constantly re-balancing and creating coherence between the activity and equality, in a constructive and cognitive tension" (Héber-Suffrin, 1998: 214).

\section{A new questioning of the economy}

The kinship between initiatives such as the popular economy, proximity services, fair trade, microfinance and social currencies is confirmed by the existence of multidimensional experiments that include elements from several. In Peru, Villa el Salvador (a shanty town of some 350,000 inhabitants near Lima) is a self-governing collectivity, which, in 1987 , set up an industrial park together with representatives of the national government. This pole of development of the popular economy, involving funding, training, support for commercialization and technical assistance, generated 30,000 jobs across 8000 small companies. In Brazil, the residents' association of Palmeiras, a shantytown on the edge of Fortaleza, became famous with the name of its popular bank, "Palmas," which supports the production of handicrafts, clothing, leather goods and cleaning materials, and also a tourist agency. This solidarity funding (involving a special neighbourhood currency) is complemented by fair trade in the form of a shop where local producers can display and sell their wares. In all cases, the establishment of the economic rules takes account of the voice of those who are usually excluded by the power relations of an economy dominated by the logic of large groups: women, the lower classes, small producers from the South, etc.

These outbursts of association-building in the last decades of the $20^{\text {th }}$ century were not about promoting an ideal, unachievable economy. ${ }^{21}$ The qualifier "alternative", which had been such a powerful mobilizing force in the $20^{\text {th }}$ century and was still marked by the imaginary of rupture, now dissipated, to be replaced by a variety of terms that refer to different kinds of initiatives.

\section{From alternative to the quest for legitimacy}

Over the long term, there has clearly been a shift away from "alternative" visions to a quest for legitimacy. The first proximity service projects were part of an alternative imaginary. After

\footnotetext{
${ }^{21}$ In this respect, some presentations are too dated and too influenced by the example of local exchange systems. Thus, Cusin \& Benamouzig (2004) make reference to them, though their general assessment has to be refuted: "the question arises of whether or not this alternative system may be generalized to the market" (208). When the matter is presented in these terms, the conclusion can only be the invalidation of an unrealistic project. The choice between "mercantile transactions or the logic of donation?" (to use the authors' terminology) is clearly biased.
} 
1968, the "crèche sauvage" movement, which arose in Paris, spread through France and other countries like Germany, where Kinderlaeden (anti-authoritarian nursery schools) were created in Berlin. The "crèches sauvages" flaunted their counter-cultural attitude and antiinstitutional aims, rejecting other collective childcare facilities and domination by institutions considered as niches of the dominant ideology. The "desire to be independent and to be able to freely formulate the quest for a new form of pedagogical and relational expression kept existing groups on the margins of public institutions, which were perceived to exert a power of control and standardization" (Passaris, 1984: 2). In Germany, according to a survey carried out in 1987 by the National Information and Liaison Office for the Development and Support of Self-Help Groups, the first generation of self-help groups was built through progressive differentiations within a dynamic of contestation that sought to produce a counter-society at local level.

In this perspective, the trajectory followed by these groups is typical of proximity services. In these childcare facilities, the dark face of the alternative impulse was unexpectedly revealed: inadequate resources, isolation, the precarious nature of its actions, high volunteer turnover rate, breadth of responsibilities compared to the gratifications taken from the experiment. When it ran out of steam, many attempts subsequently disappeared. However, despite this, their strength lay in the ability to relativize and contextualize the initial utopia, without giving it up altogether. As the aim was limited to providing services in a very restricted area, reorientation was easier than in some experiments at community living and working, where interpersonal conflicts would arise as the planned transformations grew weaker. In short, the utopian visions became tempered with realism over time, a development furthered by the economic crisis, which foregrounded concerns such as the maintenance of accessible collective services and job creation. "On the one hand, it became more difficult for parents to arrange time to participate in the functioning of the crèches as well as the money required for self-funding," while "on the other, the importance of the stability of regular paid employment was also felt" (ibid.).

Thus, these experiments experienced two waves: firstly, the alternative to mercantile consumption, and later, a certain realism with regard to questions of employment and social cohesion. In their search for meaning, they bear witness to a crisis of values expressed at the end of the 1960s, while through their realism, they internalised the obstacles produced by 
the financial crisis that followed. This dual affiliation is reflected in the reference to general values articulated with the desire to resolve concrete problems in a particular context.

The first wave of association-building introduced a logic of "voice," as direct worker and user participation acquired importance as a way of complementing the participation granted to the respective representatives. The second wave was more reactive to neoliberalism and more pragmatic. For this reason, it received an ambivalent response from supporters of the welfare state, who considered that it often extolled civil society as a substitute for state intervention. It might be said that the demand for rights of expression on the part of the citizen was confused with a desertion of the state. However, while the budgetary constraints on the welfare state played a part in engendering proximity services, they do not entirely explain the commitment shown by actors from civil society. This is also connected to the promotion of forms of active citizenship. In addition, most of the initiatives did not entail the end of state involvement; on the contrary, they sought public recognition. This recognition began to occur following the studies that described in detail the contents of proximity services in different EU countries, funded by European pilot schemes for rural development and innovation (the EC Leader initiative), the "third system" (Directorate-General for Employment and Social Affairs), regional and local strategies to support local job creation schemes, and integrated and innovative urban revitalization and restructuring strategies (Article 10 of the European Regional Development Fund). In total, at least 5000 to 6000 experiments were supported, bearing witness to the gradual visibility of initiatives that had been overlooked in the past. However, this support did not provide a place in stable budget lines, due to the market-oriented approach of public actions at European level, which for many years have confused support for a field of activity with the creation of a new market, territorial development with aid to companies. Moreover, public regulation focused upon job creation, preferring to give exemptions to consumers rather than subsidies to the supply, and gradually abandoning concern with accessibility, which was constitutive of the social services.

Further obstacles to recognition had to do with the social utility and virtually collective character of proximity services. In fact, many of these services (which were individual, as they were directed at individual consumers) also offered benefits for the collectivity. The typical example, which blurs the distinction between individual and collective services, is the case of childcare. Forms of childcare are very connected to the conception of the role and place of women in society. These services affect the lifestyle of individuals, and the collectivity 
influences the way apparently individual choices are made. Thus, public authorities are entitled to intervene in the funding of childcare for small children, for reasons of equity (including the desire to make this service accessible to as many people as possible) and quality control, and for external reasons connected to the benefits that this can bring for the community, such as releasing more women into the work force, not to mention the educational and preventive role provided by childcare facilities (Fraisse, Gardin \& Laville, 2000). The challenge to these initiatives and their respective public interlocutors lies in designing institutional formulas that take account of the collective benefits created by particular services, and respect for criteria of social justice and professional equality. Between individual and general interests, the challenge is to define the criteria of social utility that create the right to public funding and that may be subject to negotiation, extending social negotiation to partner associations and local collectivities.

However, the still-weak echo of these initiatives is due to the fact that, as they grow in size, they revive pre-established models of mercantile or state action. This is the problem of the different logics operating in these micro-collective actions and in macro-institutional regulations. The initiatives studied, through micro-collective actions, restore relations between the social and economic components. The dominant macro-institutional regulations, for their part, continue to juxtapose economic policies that justify deregulation measures with the argument of the hardness of international competition and social policies, which try to attenuate the social fragmentation accentuated by economic policies. Clearly, inadequacies will persist between actions designed to organise living conditions in accordance with the reasons for living (De Certeau, 1980) and regulations inherited from an economic society focused on resolving the problem of scarcity. It is for this reason that, given the lack of social debate about institutional mediations capable of keep up with the increase in contemporary uncertainty and the inability of macro-institutional regulations to ensure social cohesion, micro-collective actions constitute neglected phenomena, despite their relative diffusion. Paradoxically, the institutional changes that they caused were minimal, while the questions that they raised touch the fundamental choices of society. The associations are often accused of fostering job insecurity. However, before calling the actors into question, would it not be better to question ourselves about the deficit and lack of public recognition? 
It is not the desire to restrict public action that guides the associative and cooperative projects mentioned. On the contrary, those in charge of them insist that public action is indispensable, but add that public policies have to rethink the respective modes of intervention in order to integrate initiatives that aim at the democratization of society. The challenge is to define policies that support them because of their contributions, not only on the economic and social levels, but also on the political level, as they stimulate an apprenticeship in public life that favours the expression of daily problems. ${ }^{22}$

\section{A new problematic}

None of these initiatives, legally validated in diverse national contexts, may be understood through the third sector approach that establishes a watertight separation between associations and cooperatives, something that is being increasingly challenged by reality. Neither do they fall into the sphere of the previously acquired status of the social economy, but are distinguished from it by their broader solidarity aims as well as by their character as enterprises involving multiple parties. The explicit objective of service to the collectivity and power sharing between the different parties are the two most specific features of the emerging realities, and this forces us to examine their connection.

But first let us return to the objectives. From the moment economic activities are established as a means at the service of objectives related to democratic solidarity, the production of goods and services obeys another logic: it is not decided in accordance with the prospects of profit but according to whether it suits the common good. The reasons for the promoters' commitment lie in the search for benefits for the collectivity that are not effects induced by economic activity but intentional consequences. Thus, in the case of biological agriculture, renewable energies or economic integration, environmental and social costs externalized by other companies become internalized. The objectives chosen by the actors lead them to assume functions such as local heritage maintenance, environmental protection or the integration into employment of people with difficulties. In fair trade, solidarity finance and proximity services, there is also respect for criteria of social justice and accessibility to services.

The activity is not conceived on the basis of a common pre-existing identity, but through collective reflection, which helps define it. To achieve the desired objectives, one has

\footnotetext{
${ }^{22}$ This question is developed in Laville $(1995: 32-54 ; 1997)$.
} 
therefore to use appropriate means: in this case, those means reside in the grouping of the parties involved, to specify the coordinates of a supply and demand which, before, were only latent or vaguely felt. Thus, in proximity services, there are not only asymmetries of information, as stipulated in the third sector approach, but also uncertainty as to the construction of the services themselves. The common challenge facing the parties involved in the project is how to deal with this informational uncertainty in the context of an explicit quest for social justice - for example, in the equitable access to services or to a "decent" job (Laville \& Nyssens, 2001: 9-21) - or through the social construction of what are called positive externalities in conventional economics (Fraisse, Gardin \& Laville, 2001: 192-207). From the moment these benefits cease to be a phenomenon induced by economic activity and become a dimension claimed by the promoters, it is logical that these should be recruited amongst users and professionals of the activity, along with those partners, as volunteers, that believe in the legitimacy of the initiative.

Logically, the demand for collective benefits does not attract private investors and the creation dynamic resides in the mobilization of social capital. We can thus affirm that the organizing factor (according to Razeto, the factor that determines the objectives of the legal entity and enables it to be controlled) is, in this case, social capital. This capital may, in addition, be more specifically termed civic capital (Evers, 2001), as it seeks collective benefits, activating democratic social ties. While social capital is important in the whole production process, in the initiatives considered, it becomes the organizing factor of production and acquires a civic orientation.

This is what the solidarity economy aims to witness, when it insists on the process of democratization of the economy that gathers all these initiatives. Using Lipietz's terminology (2001), "we do it in the name of this" overrides "how we do it, under what status and with what organizational standards" - i.e., the rules of the social economy. The solidarity economy has brought to public attention notions of social utility and collective interest, and raised the question of the aim of activities, something that had been sidestepped in the social economy, which centred on the relations between activity and actors. On this point, the solidarity economy goes further than the social economy. 


\section{A dual dimension}

The dual dimension, political and economic, demanded by the solidarity economy and schematized in the diagram below, underlines the need for associative, cooperative and mutualist experiments to influence institutional commitments. The social economy, centred on the organizational aspect, has not bee able to counter the institutional isomorphism created by the division and complementarity between market and welfare state. Centred on the economic success of the companies that compose it, it has put aside political mediations. Indeed, as a reaction to the perverse effects of that focus on the economic dimension, the experiments of the last decade have reinforced the political dimensions of initiatives that aim to be both citizen-oriented and entrepreneurial. These will have no effect if they are unable to promote democracy in both their internal functioning and their external expression.

Figure 1: The two dimensions of the solidarity economy

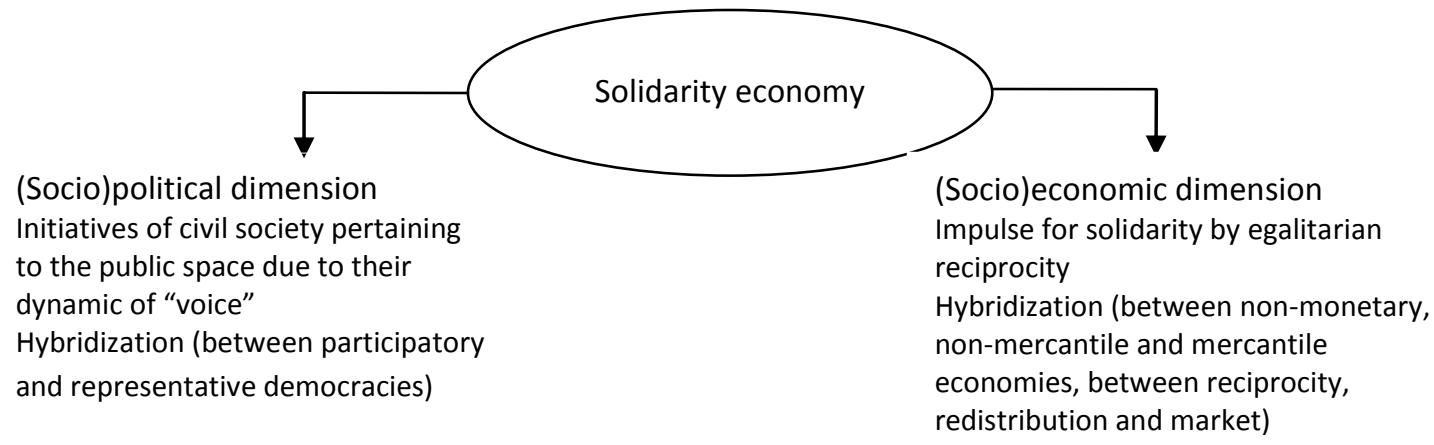

Tensions between
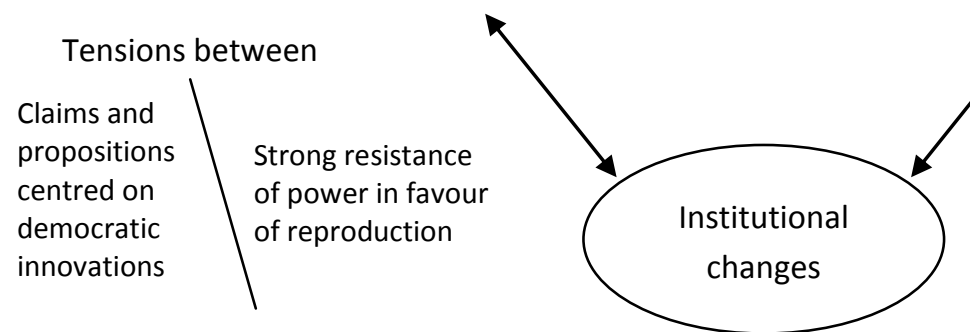
redistribution and market)

To admit that the economic success of isolated experiences is not decisive also means engaging in reflection about the reasons why they encounter so many obstacles to their diffusion. In this respect, there must be a dominant definition of the economy that discriminates negatively against them. If this solidarity economy has no right to a full existence, this is not due to any inadequacy on the part of its actors, but to a more fundamental reason. Through its dual dimension, the solidarity economy questions the 
categories of the economy at the conceptual and empirical level, refusing to limit economic phenomena to those that are defined as such by economic orthodoxy. It also questions this power of delimitation that economic science possesses, and fosters a more general reflection on the definitions and institutions of the economy. ${ }^{23}$

Translated by Karen Bennett

Revised by Teresa Tavares

\section{References}

Alcoléa-Bureth, A.-M. (2004), Pratiques et Theories de l'Économie Solidaire. Paris: L'Harmattan.

Autogestions (1981), "Les habits neufs du président Tito: Critique sociale, répression politique et luttes ouvrières en Yougoslavie," Revue Autogestions, no. 6. Toulouse: Privat.

Berger, A.; Fraisse, L.; Hersent, M. (2000), "Femmes et économie solidaire," Sciences de l'homme et sociétés/ Cultures en mouvement, 31 (October).

Blanc, J. (ed.) (2006), Exclusion et liens financiers. Monnaies sociales. Rapport 2005-2006. Paris: Economica.

Carvalho, H. Martins de (2002), "A emancipação do movimento no movimento de emancipação social continuada," in Boaventura de Sousa Santos (ed.), Produzir para viver. Os caminhos da produção não capitalista. Rio de Janeiro: Civilização Brasileira, 233-260.

Cérézuelle, D. (2004), "Autoproduction et développement social," Hermès - "Economie solidaire et démocratie," 36, 101-108.

Collombon, J.-M.; Barlet, S.; Ribier, D. (2004), Tourisme solidaire et développement durable. Paris: Les Editions du GRET.

Coraggio, J. L. (1999), Politica social y economia de trabajo. Madrid/Buenos Aires: Minio y Davila Editores.

Corpet, O. (1982), "Collectifs d'intervention et mouvements alternatifs," Communautés, 62 (OctDec).

Corpet, O.; Hersent, M.; Laville J.-L. (1986), "Le savoir sans privilèges," Revue internationale d'action communautaire, 15/5, Montreal.

Cusin, F.; Benamouzig, D. (2004), Economie et sociologie. Paris: Presses Universitaires de France.

Dahrendorf, R. (1972), Classes et conflits de classes dans la société industrielle. Paris-La Haye: Mouton.

De Certeau, M. (1980), La culture au pluriel. Paris: Christian Bourgois.

De Soto H. (1987), El otro sendero. Buenos Aires: Editorial Sudamericana.

Defourny, J.; Favreau, L.; Laville, J.-L. (1997), Insertion et nouvelle économie sociale. Paris: Désclée de Brouwer.

\footnotetext{
${ }^{23}$ It is in this perspective that it participates in economic sociology, although, as argued by Cusin \& Benamouzig (2004: 12), the latter "refuses to be subordinated to the specific problems of economic theory," encouraging "a more general reflection about the role of the economy in modern societies."
} 
Demoustier, D.; Rousselière, D.; Clerc, J. M.; Cassier, B. (2003), "L'entreprise collective: Unité et diversité de l'économie sociale et solidaire," RECMA - Revue internationale de l'économie sociale, 82(290), 56-73.

Desroche, H. (1976), Le Projet Coopératif. Paris: Editions Ouvrières.

Eme, B. (2005), Sociologie des logiques d'insertion. Processus sociopolitiques et identités, Ph.D dissertation in Sociology. Paris: Sciences Po.

European Commission (1993), Croissance, compétitivité et emploi. Débats et voies pour entrer dans le XXlème siècle. Livre blanc de la Commission des Communautés Européennes. Luxembourg

European Commission (1995), Les initiatives locales de développement et d'emploi. Brussels (March).

European Commission (1996), Le premier rapport sur les initiatives locales de développement et d'emploi. Des leçons pour les pactes territoriaux et locaux pour l'emploi. Working document of the Commission Services (November).

Evers, A.; Laville, J.-L. (eds.) (2001), The Third Sector in Europe. London: Edward Elgar.

Evers, A.; Bode, L.; Gronbach, S.; Graf, A. (1999), The Enterprises and Organisations of the Third System: A Strategic Challenge for Employment. National Report Germany, CIRIEC, Working Group 1, Liège.

Folbre, N. (1997), De la différence des sexes en économie politique. Paris: Des Femmes.

Fraisse, L.; Gardin, L.; Laville, J.-L. (eds.) (2000), Le fonctionnement socio-économique du Troisième système. Recherche européenne pour la Direction de l'Emploi et des Affaires Sociales (DGV) de la Commission des Communautés Européennes.

Gardin, L. (2006), Les initiatives solidaires. Ramonville: Erès.

Gardin, L.; Laville, J.-L. (2000), Evaluation de la politique régionale de soutien au développement de nouvelles activités, nouveaux services. Paris: CRIDA.

Gendron, C. (2004), "Mouvements sociaux", in J.-L. Laville \& A. D. Cattani (eds.), Dictionnaire de l'autre économie. Paris: Desclée de Brouwer, 395-402.

Glémain, P. (2006), Pour une sociologie économique des finances solidaires. Ecole doctorale Entreprise-Travail-Emploi, Paris: CNAM.

Guérin, I. (2003), Femmes et économie solidaire. Paris: La Découverte.

Guérin, I. (2007), "Economie solidaire et rapports de genre," in J.-L. Laville (ed.), L'économie solidaire. Une perspective internationale. Paris: Hachettes Littératures, 282-304.

Héber-Suffrin, C. (1992), Échanger les savoirs. Paris: Desclée de Brouwer.

Héber-Suffrin, C. (1998), Les savoirs, la réciprocité et le citoyen. Paris: Desclée de Brouwer.

Hirschman, A. O. (1971), Exit, Voice and Loyalty: Responses to Decline in Firms, Organizations and States. Cambridge, Mass.: Harvard University Press.

Huber, J. (1981), “Projets auto-organisés et réseaux d'entraide," Futuribles, 40 (January), 31-45.

Inglehart, R. (1977), The Silent Revolution: Changing Values and Political Styles among Western Publics. Princeton: Princeton University Press.

Jouen, M. (1995), Les initiatives locales de développement et d'emploi. Brussels: Commission Européenne (March).

Klausen, K.; Selle, P. (1996), “The Third Sector in Scandinavia," Voluntas, 7(2), 99-122. 
Laville, J.-L. (1995), "La crise de la condition salariale," Esprit - "Vers une société de pluriactivité?", 12 (December).

Laville, J.-L. (1997), Le travail, quel avenir? Paris: Gallimard.

Laville, J.-L.; Sainsaulieu, R. (1997), Sociologie de I'association. Paris: Desclée de Brouwer.

Laville, J.-L.; Nyssens, M. (eds.) (2001), Les services sociaux entre associations, Etat et marché. L'aide aux personnes âgées. Paris: La Découverte.

Leichsenring, K. (1997), The Role of the Labour Market Service in Supporting Non-Statutory Childcare Providers. Vienna: European Centre for Social Welfare Policy and Research.

Lewis, J. (2003), "Gender and Welfare State Change," European Societies, 4(4), 331-357.

Lipietz, A. (2001), Pour le tiers secteur. L'économie sociale et solidaire pourquoi et comment. Paris: La documentation française-La Découverte.

Lorendahl, B. (1997), "Integrating the Public Sector and Cooperative Social Economy. Towards a Swedish New Model," Annals of Public and Cooperative Economics, 68(3).

Mance, E. (2006), "Consommation solidaire," in J.-L. Laville \& A. D. Cattani (eds.), Dictionnaire de l'autre économie. Rev. ed. Paris: Folio-Actuel, Gallimard.

Melucci, A. (1983), "Mouvements sociaux, mouvements post-politiques," Revue internationale d'action communautaire, 10/50 (Autumn), 13-30.

Mothé, D. (2004), “Autogestion,” in J.-L. Laville; A. D. Cattani (eds.), Dictionnaire de l'autre économie. Paris: Desclée de Brouwer, 53-60.

Navarro, Z. (2002), "'Mobilização sem emancipação' - as lutas sociais dos sem-terra no Brasil," in Boaventura de Sousa Santos (ed.), Produzir para viver. Os caminhos da produção não capitalista. Rio de Janeiro: Civilização Brasileira, 189-232.

Neveu, E. (1996), Sociologie des mouvements sociaux. Paris: Repères - La Découverte.

Nyssens M. (2006), Social Enterprise between Market, Public Policies and Civil Society. London: Routledge.

Passaris, S. (1984), La participation parentale dans les modes de garde de la petite enfance, 4 vols. Paris: CIRED, Ecole des Hautes Etudes en Sciences Sociales.

Pestoff, V. (1998), Beyond the Market and State: Social Enterprises and Civil Democracy in a Welfare Society. Aldershot, UK: Ashgate.

Pestoff, V. (2004), "The Development and Future of the Social Economy in Sweden," in A. Evers; J-L. Laville (eds.), The Third Sector in Europe. Cheltenham, UK: Edward Elgar, 63-82.

Prouteau, L. (ed.) (2003), Les associations entre bénévolat et logique d'entreprise. Rennes: Presses Universitaires de Rennes.

Quijano, A. (1998), La Economia Popular y sus caminos en America Latina. Lima: Mosca Azul Editores.

Razeto, Luis (1993), Empresas de trabajadores y economia de mercado.Santiago de Chile: Ediciones PET.

Richez-Battesti, N.; Gianfaldoni, P.; Gloukoviezoff, G.; Alacaras, I. R. (2006), “Quelle con- tribution des banques coopératives à la cohésion sociale des territories. Une approche en termes d'innovation sociale," paper presented to the 20th Conference of ADDES, 7 March, Paris.

Ritimo-Solagral (1998), Pour un commerce equitable. Paris: Éditions Charles Leopold Mayer, La Librairie Fondation pour le Progrès de l'Homme. 
Rodriguez, C. (2002), "A procura de alternativas económicas em tempos de globalização: O caso das cooperativas de recicladores de lixo na Colômbia," in Boaventura de Sousa Santos (ed.), Produzir para viver. Os caminhos da produção não capitalista. Rio de Janeiro: Civilização Brasileira, 329367.

Scholnik, M. (1984), "Les organisations économiques populaires et la vie quotidienne," Nouvelles de l'écodéveloppement, 31, supplement to MSH information (December).

Schumpeter, J. A. (1943), Capitalism, Socialism and Democracy. London: Allen and Unwin.

Servet, J. M. (2006), Banquiers aux pieds nus. La microfinance. Paris: Odile Jacob.

Taylor, M. (2004), The Welfare Mix in the United Kingdom. Cheltenham, UK: Edward Elgar.

Touraine, A. (1978), La voix et le regard. Paris: Seuil.

Verano, F. (2001), "La economia solidaria una alternativa de desarrollo con equidad y iusticia social para construir la paz - un aporte para la reflexion y accion." Bogotá: COLACOT (available online in http://groups.yahoo.com/group/rgses/files/ Economa1.doc).

Vienney, C. (1980-1982), Socio-économie des organisations cooperatives. Paris: Éditions CIEM, 2 vols. 